\title{
An Englishman in Vartov Church, 1872
}

\author{
Edmund Gosse, Two Visits to Denmark 1872, 1874 (London, \\ 1911), Ch. V, 78-87.
}

\section{By S. A. J. Bradley}

The Englishman Sir Edmund William Gosse (1849-1928) was, in his day, a significant and influential literary figure - poet, essayist and biographer - and at various times cataloguer in the British Museum, translator in the Board of Trade, Librarian to the House of Lords, lecturer in the University of Cambridge, and columnist for the Sunday edition of the Times. In 1879 he published his Studies in the Literature of Northern Europe. He is generally credited with having made the genius of Ibsen known to the English-speaking world, collaborating with William Archer in the translation of Hedda Gabler and The Master Builder. Otherwise he is now remembered and read chiefly for his autobiographical work Father and Son: A Study of two Temperaments, treating of his troubled relation with his father, the zoologist Philip Henry Gosse (1810-1888).

As a young man in his early twenties he visited Denmark, residing in Copenhagen as guest of Dr Bruun Juul Fog (1819-96), Provst (Dean) at Holmens Church and later bishop in Aarhus, and his unmarried sister Aline. The account of these visits was not published until many years afterwards, a fact which entitles us to be at least a little circumspect in our acceptance of Gosse's record. The raconteur is also strong in him and one may suspect that he is impelled as much by the motive of telling a good story well, as by a sense of strict duty towards fact. Yet there is in him a refreshing independence of mind. $\mathrm{He}$ is in some respects a very English Englishman, and yet he is as indignant at the English fire-bombardment of the civilian population of Copenhagen as he is of the Prussian bombardment of the Danish island of Als. He can say quite frankly that he does not like Grundtvig's writings, and he can liken the old man's appearance in Vartov Church to that of a troll, but he makes a just and admiring assessment of Grundtvig's role in gaining liberties for the people of Denmark and in helping to hold the nation together in a period of deep crisis. Despite its shortcomings as historical documentation, Gosse's impressionistic account of the atmosphere in Vartov Church in Grundtvig's last days is surely a remarkable and valuable testimony. The work was translated into Danish by Valdemar Rørdam (1912) as Edmund Gosse: To Besøg i Danmark 1872-74.

Henrik Nicolai Clausen (1793-1877) was Professor of Theology in Copenhagen from 1822; publication of his Catholicismens og Protestantismens Kirkeforfatning, Lare og Ritus (1825), informed by rationalism in the school of Schleiermacher, provoked Grundtvig's protest in Kirkens Gienmoele (1825). Grundtvig was deemed to have libelled Clausen, and was fined and placed under 
censorship.

Hans Lassen Martensen (1808-84) was Bishop of Sjælland from 1854, achieving some international status as a theologian; in the 1830s he associated admiringly with Grundtvig to the extent of supporting the idea of a Grundtvighymnal; but subsequently his role as a chief mediator of Heglian philosophy in Denmark defined the extent to which he diverged from Grundtvig's positions, and eventually, as bishop, he became Grundtvig's stubborn adversary.

It is difficult today, it was almost impossible forty years ago, to discover the immediate past history of a little country like Denmark from the latitude of London. The domestic incidents of immediately recent years are chronicled in no book of reference that is within reach of a foreigner. Hence it was on the mere presumption that a man born ninety years before was not likely to be still alive, that I said at breakfast this morning, 'How I wish I had come to Denmark during the lifetime of Grundtvig!' There was a shout from every one, 'But he $i s$ alive, and he still preaches every Sunday morning in the Workhouse Church!' 'This is Sunday morning - I must listen to a poet who was born five years before Byron, and who recollects the execution of Louis XVI. Where is this Workhouse Church ?' But thereupon there fell a silence, and my friends looked at one another with a dubious and deprecating expression.

The North at that time contained no more extraordinary man than Nikolai Severin Grundtvig. He was born, in 1783, in the country parsonage of Udby, in the strictest odour of orthodoxy, a typical child of the manse. He entered the church early, but did not become a parish priest until 1821. By that time he had formed the view that the Danish ecclesiastical system was too precise and too frigid, and he determined to amend it. Pharisaism and rationalism - those were the two bugbears of his long fighting career. He attacked them in high places, in the person of Clausen, then the leader of official theology in Denmark. The immediate result was that Grundtvig was driven out of his incumbency in 1826 . He now became a species of outcast, in a protestant society which did not tolerate nonconformity, and he entered upon nothing less than a war with Church and State. He called for the formation of a 'People's Church' outside the State, and for complete liberty in liturgical and dogmatic opinion.

Not more than the briefest outline of an extremely interesting career must be attempted here. Grundtvig had something primitive about his character, an intensity of purpose which made him maddening to those whom he opposed, an object almost of idolatry to those whom he hypno- 
tised. Denmark had languished under an ecclesiastical bondage too grievous to be borne in its puritanical coldness and formality. It was Grundtvig who first gave expression, often in violent and illogical language, to the popular sense of sacerdotal oppression. There was nothing, as I understand it, very dogmatic about his teaching. He went straight back to the Bible, and indeed almost exclusively to the Gospels. He took the Lord's Prayer and the Sermon on the Mount as a basis of practical Christianity. But he was a passionate lover of liberty, and his sympathy for those whom orthodoxy treated as rebels was incessant. He was, in consequence, himself treated as a rebel. All the fires of orthodoxy and formalism were concentrated on his head. But he was a magnificent fighting man; he never consented to give way; he wrote, and preached, and hurried from parish to parish, while in process of time he gathered about him a cloud of passionately devoted disciples. There was a faint resemblance between his career and that of John Wesley.

Like all prophets, Grundtvig was intensely and exclusively national. He was not merely a leader of religious reform; he was a mythologist, because in the old faith he saw evidences of natural piety; he was an editor of the ancient sagas, because Danes ought to know the primitive history of their race; he wrote hymns and patriotic poems, because the Christian should mightily rejoice in God with a loud noise of singing. As the Church would grant him no incumbency, he appealed to the people, and he became a radical politician, who sat successively, and spoke often, in the Folketing and in the Rigsdag. He was a violent partisan of Denmark against Germany upon every occasion, and his enemies said that his object in religious controversy was mainly to turn the German theology out of the teaching of the schools. Occasionally, like a prophet of old, Grundtvig would make a sudden appearance at the courts of kings, and he had the art to command respectful attention there. The priests were his enemies, he said, not the monarch; and indeed he so impressed Frederik III [thus Gosse; actually Frederik VII] that in 1861 that King appointed him titular bishop, without a see, to the intense vexation of the real bishops, who continued to exclude him from all the pulpits in their dioceses. It was to an earlier monarch, indeed, that Grundtvig owed the power to preach at all. Christian VIII, on his accession in 1839, finding that the poet-prophet had no place for the sole of his foot in any State church, appointed him chaplain to the Vartou, or workhouse. There he remained, never making peace with the ecclesiastical authorities, until the close of his long life.

He was preaching at the Vartov one Sunday in 1867, when his 
gestures became more and more extravagant, and he went mad in the pulpit. But after a short period of retirement he recovered self-control. Perhaps an element of not perfect mental health in his extreme individuality was required to enable the divine logos in him to breathe through his speech articulately. His disciples, at all events, cared not whether he were sane or insane. He held up before them over and over again, with passionate vivacity, the ideals of his life - perfect love, perfect liberty, enthusiasm for the Fatherland, hope for the future of Denmark. From the Workhouse Church, a new sect, soon calling themselves Grundtvigians, extended all over the country, and even over Norway and Sweden. The pedagogic instinct was strong in Grundtvig, and he fostered the didactic spread of his own opinions. Encouraged by King Christian VIII, against the united wish of the Bishops and the Government, he began to set up 'folk-highschools' in every direction. His disciples became the more devoted to him the more that the sanhedrin derided him. He must have been lovable to the so ardently beloved, but he was not less ardently detested. The priests were his natural enemies, and the whole energy of a multifarious career may be summed up in saying that he succeeded in breaking down the despotism of Scandinavian official religion. He tore away, from men's consciences all the obligatory tests and the deadening formulas, all the totafoth and zizith of the scribes and Pharisees.

The writings of Grundtvig, whether in prose or verse, have never been attractive to me. They are so exclusively national as to be scarcely intelligible to a foreigner; they lie, if I may say so, outside the European tradition. But as a human being, as a documentary figure in the history of his country, no one could be more fascinating. That he should still, at the extreme age of ninety, be existing and visible seemed an element on which the youthful adventurer might warmly congratulate himself. So fragile an apparition, so incredibly delayed (as it seemed) on my particular behalf, might, at the smallest sign of neglect, be inevitably and finally withdrawn. I conceived my Genius, with awful finger uplifted, saying, 'You might have heard Bishop Grundtvig preach, and were too idle to do so. Very well; he expires to-night!' It was evident that, at all hazards, Grundtvig must be visited. But how to do it without giving offence to my generous host I knew not, since Dr. Fog had been one of the reformer's most determined opponents.

Miss Aline Fog forestalled my apologies by saying, 'Of course you can go alone to hear Bishop Grundtvig preach. But I am afraid you must not expect us to countenance such a dangerous schismatic.' The Dean 
was in one of his statuesque attitudes; in his violet eyes curiosity, it suddenly struck me, was contending with a sense of propriety. 'Aline,' he said, 'I don't feel sure that we ought to say 'schismatic'.' I have always strenuously opposed his teaching, as Clausen did and as Martensen does; but I admit, when we take away the personal elements, the irritating manner, and the false rhetoric, that the differences between Grundtvig's creed and ours are only just enough to keep the party flag flying. And the passage of time - he is so old! I declare I feel tempted to accompany our young friend to the Vartov myself !' 'Impossible, my brother!' said the ecclesiastically agitated spinster. 'On the contrary, not only possible, but now decided upon,' replied the Dean. 'I do not preach to-day. I have not set eyes on Grundtvig for years and years. We must indeed make some haste or we shall not see him now'; and he rose to put on his clerical dress.

We arrived, however, so far as seeing the great man was concerned, in most ample time at the little Workhouse Church, opposite the trees and still waters of the western ramparts. We found seats with difficulty, the chapel being crowded with communicants, doubtless attracted by a rumour that this would be the last time that the aged prophet would address his disciples. After sitting more than half an hour, surrounded by strange, fanatic faces, and women who swung themselves backward and forward in silent prayer, the word was passed round that the Bishop would probably be unable to come. The congregation began to sing hymns of his composition in a loud, quick, staccato manner invented by the poet, which was very little like the slow singing in the State churches. Suddenly, and when we had given up all hope, there entered from the vestry and walked rapidly to the altar a personage who seemed to me the oldest human being I had ever seen. Instantly an absolute silence prevailed throughout the church, and then there rose a sound as though some one were talking in the cellar below our feet. It was the Bishop praying aloud at the altar, and then he turned and addressed the communicants in the same dull, veiled voice. He wandered down among the ecstatic worshippers, and stood close at my side for a moment, while he laid his hands on a girl's head, so that I saw his face to perfection. For a man of ninety, he could not be called infirm; his gestures were rapid and his step steady. But the attention was riveted on his appearance of excessive age. He looked like a troll from some cave in Norway; he might have been centuries old.

From the vast orb of his bald head, very long strings of silky hair fell over his shoulders and mingled with a long and loose white beard. His 


\section{5}

eyes flamed under very beetling brows, and they were the only part of his face that seemed alive, for he spoke without moving his lips. His features were still shapely, but colourless and dry, and as the draught from an open door caught them, the silken hairs were blown across his face like a thin curtain. While he perambulated the church with these stiff gestures and ventriloquist murmurings, his disciples fell on their knees behind him, stroking the skirts of his robe, touching the heels of his shoes. Finally, he ascended the pulpit and began to preach; in his dead voice he warned us to beware of false spirits, and to try every spirit whether it be of God [1 John 4:1]. He laboured extremely with his speech, becoming slower and huskier, with longer pauses between the words like a clock that is running down. He looked supernatural, but hardly Christian. If, in the body of the church, he had reminded me of a troll, in the pulpit he looked more like some belated Druid, who had survived from Mona and could not die. It was an occasion of great interest to me. Had I missed hearing and seeing Grundtvig then, I should never have heard or seen him, for he took to his bed a few days later, and in a month the magnificent old fighting man was dead. 